Article

\title{
Participation as a Christian Ethic: Wojtyla's Phenomenology of Subject-in-Community, Ubuntu, and the Trinity
}

\section{Neil Pembroke}

School of Historical and Philosophical Inquiry, The University of Queensland, Brisbane 4072, Australia; n.pembroke@uq.edu.au

Received: 22 October 2018; Accepted: 14 January 2019; Published: 17 January 2019

\begin{abstract}
Participation is defined as being-with and acting-for others with the aim of advancing the common good. Karol Wojtyla's philosophy of community and the Sub-Saharan ethic known as Ubuntu are used to describe a participative ethic. These philosophies approach participation in a particular way - namely, through positing both an 'I-Thou' and a 'We' dimension. Neither in Wojtyla's philosophy, nor in Ubuntu, do we find references to Christian theology. Though it is evident that these philosophies incorporate certain moral values embraced by the Christian community, it is necessary to make the theological alignment explicit. The main aim of the essay is to do just that. It is argued that participation is rightly construed as a Trinitarian ethic.
\end{abstract}

Keywords: participation; Trinity; subjectivity; community; Ubuntu

\section{Introduction}

In everyday usage, 'participation' is simply the act of taking part in something. For example, people participate in social groups, in sporting activities, and in the political process. The focus here is on participation as a moral activity. Stated succinctly, the virtue of participation is being-with and acting-for others with the aim of advancing the common good (cf. Wojtyla 1979a, 1979b). Personalist philosophers such as Martin Buber (1961, 1970), Ferdinand Ebner (1967, 2001), and Gabriel Marcel (1964a, 1964b), each in their own way, offer an understanding of participation founded on an I-Thou relation. What characterizes the I-Thou relation is intersubjectivity; the partners participate in the relation as subjects rather than 'its'. That is, the philosophy of intersubjectivity refuses the human tendency to make the other into a thing; it supports subjectivity rather than object-ification. An adequate ethical treatment of participation needs to begin at the level of the I-Thou relation. I suggest, though, that the virtue of participation reaches its fullest expression through the incorporation of a 'We' dimension. That is to say, an adequate articulation of a participative ethic incorporates both positive interpersonal relations and commitment to the common good.

In order to articulate some of the essential elements in a participative ethic, I draw upon Karol Wojtyla's (John Paul II) work on subjectivity and community (Wojtyla 1979a, 1979b) and descriptions of the sub-Saharan participative ethic of Ubuntu. In this African ethic, persons are viewed as interdependent entities whose deepest moral obligation is to become more fully human through expressing virtues such as hospitality, generosity, and compassion.

In Wojtyla's thought and in philosophical discussions of Ubuntu, there are no overt Christian theological references. Wojtyla opts to strictly follow his phenomenological method, and while Ubuntu does have a theological orientation, it is a traditional African, rather than a Christian Trinitarian, one (Mkhize 2008; Manganyi and Buitendag 2013). The theological work that I do makes the argument that Christians, together with all people of good will, who live a participative ethic mirror-albeit only very 
dimly_the perichoretic life, or co-inherence-in-love, of the Trinity. Indeed, David Cunningham (1998) refers to participation as one of the essential Trinitarian 'virtues' (he identifies three such virtues). His argument is that the life of the triune God is characterised by participation-through-love.

Cunningham (1998) provides a very useful lead; I provide a supplement to his work by attending to both the I-Thou and the 'We' elements. There is a tradition in Trinitarian theology represented by Augustine, Thomas Aquinas, and more recently by Heribert Mühlen, in which the Holy Spirit is construed as the 'We', as the mutual love between the Father and the Son. Mühlen's (1963) Trinitarian theology mirrors the expansion in Wojtyla's thought and in Ubuntu from the I-Thou level to the communal or 'We' level. He posits the Holy Spirit as the personal agency representing the extension of the divine self-love expressed in the mutuality of the I-Thou relation between the Father and the Son; the triune God lives and loves not only through an I-Thou relation, but also through a We-relation.

While Wojtyla's philosophy of participation and Ubuntu are closely linked in terms of a commitment to positive interpersonal relations and promotion of the common good, there are also significant cultural and ideological ${ }^{1}$ differences in play. It is therefore necessary to point out where the two moral systems embrace and refuse each other. In relation to the latter, while Wojtyla holds agency, self-realisation and self-possession in tension with serving the needs of the group, Ubuntu has a tendency to encourage domination and oppression of the individual. I suggest that both Wojtyla's philosophy and Trinitarian theology provide an important corrective to Ubuntu's shadow side.

The essay is structured as follows. First, there is a description of Wojtyla's phenomenology of subjectivity and community. This is followed by a discussion of the Ubuntu ethic. Next, there is a discussion of the relationship between Wojtyla's thought and Ubuntu. Finally, I call upon insights offered in select Trinitarian theologies (Moltmann, McCall, Mühlen, and Cunningham) to make the case that participation is a Trinitarian ethic.

\section{Wojtyla: The I-Thou Relation and the 'We-Attitude' in Social Life}

In his book, The Acting Person, Wojtyla (1979a) is primarily interested in developing a theory of human subjectivity as it is constituted through existence and agency. However, this project eventually leads him to a consideration of the social life of the acting person. In this regard, participation is the central concept. By participation, he means the ability to act with others in such a way as to simultaneously realize all that results from communal acting, on the one hand, and the personalistic value of one's action, on the other (Wojtyla 1979a, p. 271). That is, the person who participates is able to be-with and act-with others in a manner that allows her to be herself and to fulfil herself.

Wojtyla (1979a) introduces another concept that extends our understanding of the acting person participating in social existence-namely, the neighbour. The neighbour is one who is capable not only of being-with and acting-with others, but also of participating 'in the very humanness' of others (Wojtyla 1979a, p. 294). He concludes that 'this participation serves the fulfilment of persons in any community in which they act and exist. The ability to share in the humanness itself of every man is the very core of all participation and the condition of the personalistic value of all acting and existing 'together with others' (Wojtyla 1979a, p. 295: emphasis in the original).

Alienation is the antithesis of participation (Wojtyla 1979b). Participation describes a moral stance in which the other is viewed as a neighbour, one to whom love, friendship, and respect are due. When the other is construed as a stranger, as one to whom no moral obligations are attached, there is no possibility of participation. This failure of participation involves the failure of the self to realise itself.

Clearly, the notions of participation and neighbour are very significant ones in the context of communal life. However, Wojtyla (1979b) considers that what he offered in The Acting Person is not yet a theory of community. In an article entitled, 'The Person: Subject and Community', he sets out to rectify this deficiency. In order to develop his theory, Wojtyla (1979b) works with two profiles or dimensions

1 The term 'ideological' here means a habitual way of thinking about self and world. 
of communal life. The first one is the interhuman or the interpersonal, and it is symbolized by the pattern 'I-you'. The second one has a character that is less interhuman than social; it is symbolized by the pattern 'we'.

In tracking the contours of the first profile, Wojtyla (1979b) begins with the well-established principle in personalist philosophy (Buber, Marcel, et al.) that the ' $\mathrm{I}$ ' is constituted by the 'you'. His aim is to extend and develop this fundamental truth. He does so by making strong connections with a concept that is vitally important in his philosophy-namely, subjectivity. Through agency which is simultaneously self-determination, the human person experiences herself as a subjective structure of self-domination and self-possession. But more than this, in order for the personal subject to be truly herself, she must constantly move in the direction of transcendence. Self-transcendence is the state of the person who acts in accordance with the requirements of the true and the good.

The way in which Wojtyla (1979b) develops his understanding of the 'I-you' relation in terms of transcendent subjectivity is as follows. He begins by observing that the 'you' is another ' $\mathrm{I}$ ', different from my ' $I$ '. When I say 'I' I express a relation that reaches out beyond me, but at the same time comes back to me. 'You' is therefore at once a term of distinction or separateness, and a term of communion or contact. The other, the 'you,' helps me to more fully affirm my own ' $\mathrm{I}$ '. 'In its basic shape the relation "I-you" does not lead me out of my subjectivity; on the contrary, it establishes me in it more firmly' (Wojtyla 1979b, p. 294).

Wojtyla (1979b) suggests that there is a normative dimension associated with a reciprocal affirmation of subjectivity. The ' $\mathrm{I}$ ' should reveal the 'you' to herself in her deepest structure of self-possession and self-domination, and vice versa. In particular, what should be revealed is the tendency to self-fulfillment which witnesses to the transcendence that is the true character of the human as a person. The 'I-you' relation has the capacity to reveal the truth of each person's personhood, but more is needed. In the interhuman encounter, a person needs to be accepted and confirmed in her authentic selfhood. Wojtyla (1979b) puts it this way:

'Community' means 'that which unites.' In the relation 'I-you' there is formed an authentic interpersonal community in some shape or variety only if ' $I$ ' and 'you' remain in mutual confirmation of the transcendent value of the person-also understood as 'dignity' —and confirm this by their acts. (p. 297)

Wojtyla (1979b) considers that it is vitally important in developing a theory of community to distinguish the interhuman from the social dimension. As we have seen, the social profile is symbolized by the 'we'. The 'we' indicates many 'I's' acting in common, and 'in common' means that the existence and action of the collection of ' $I$ 's' is oriented to some value. This value is the 'common good'. In this way, Wojtyla makes a distinction between the 'I-you' and the 'we':

The relation of the many 'I's' to the common good seems to be the very core of the social community. Thanks to this relation, people who experience their personal subjectivity, and therefore the actual plurality of human 'I's,' realize that they are a definite 'we' and experience themselves in this new dimension. Although the person remains herself, this is a social dimension. It differs from that of the 'I-you,' for the direction of the dimension is changed and is indicated by the common good. In this relation the 'I' and the 'you' find their reciprocal reference in a new dimension: they discover their 'I-you' through the common good which constitutes a new unity among them. (Wojtyla 1979b, p. 298)

Wojtyla's philosophical analysis identifies commitment to the common good as the factor that conveys the ' $\mathrm{I}$ ' and the 'you' to a different level of shared life-namely, one that is constituted through a new unity. It is only when the plurality of 'I's' turn together toward the common good that they become a 'we'. Though it belongs to a very different cultural and ideological context, we find the same essential emphases in Ubuntu. It is to a treatment of this African communitarian ethic that we now turn. 


\section{A Sub-Saharan Participative Ethic: Ubuntu}

Describing Ubuntu is far from a straightforward task. First, there is no consensus amongst scholars on what the term means. Second, we are not sure whether Ubuntu should be thought of primarily as a moral quality a person possesses or as a philosophy or worldview. Gade $(2011,2012)$ uses the results of analysis of historical discourse and empirical work to show that those who discuss Ubuntu give answers that fall into both camps. Finally, some scholars have argued that intellectual approaches to Ubuntu, far from representing a straightforward description of a clearly defined traditional African or sub-Saharan African ethic or philosophy, are actually reconstructions or reinterpretations carried out at a distance of residues of patterns of thinking and behaving from village life (Van Binsbergen 2001; Bernstein 2002). In the short space available here, I cannot hope to settle these difficult questions.

A good way to get a sense for what Ubuntu means is to reflect on Desmond Tutu's very helpful description of it:

[Ubuntu means] we belong in a bundle of life. We say, 'a person is a person through other people'. It is not 'I think therefore I am'. It says rather: 'I am human because I belong'. I participate. I share. A person with Ubuntu is open and available to others, affirming of others, does not feel threatened that others are able and good; for he or she has a proper self-assurance that comes from knowing that he or she belongs in a greater whole ... (Tutu 1999, p. 35)

Also helpful in getting a feel for Ubuntu is to engage with stories in which it features. I have chosen one that Augustine Shutte uses in his book, An Ethic for a New South Africa. It was told to him by the son of a former magistrate in what was at the time Northern Rhodesia.

Traditional courts, presided over by traditional officials, were still allowed to deal with the most serious cases. These courts took place in the villages from which cases came, usually in some central space in the open air. Both sides would be allowed their say, calling friends and witnesses to support them. The courts were open and there was always an audience. At a certain point in the proceedings the audience would be allowed to comment. Sometimes the magistrate would ask the opinion of people in the audience whom he thought may be able to throw light on the subject. Sometimes he would even listen to the opinion of a passer-by. (Shutte 2001, p. 20)

For those of us who know only the extreme individualism of the Western urbanised milieu, the process of the Rhodesian court presents as most unusual. Having gleaned something of what the traditional African ethic is about through this story, let us go further.

The starting point in scholarly descriptions of Ubuntu is usually a reference to participatory humanness as captured in the Zulu saying umuntu ngumuntu ngabantu. Put simply, this is the notion that personhood is established in and through communal life. Ramose (1999, p. 52) contends 'that to be a human be-ing is to affirm one's humanity by recognising the humanity of others and, on that basis, establishing humane relations with them'. In this philosophy of personhood, relationality is the central reality. Shutte (2001, p. 23) points out that in the Ubuntu worldview a human self is not something that first exists on its own and then later enters into relationship with others. Rather, it only exists in relationship to others.

I note, further, that some writers use the language of both a philosophy or worldview, on the one hand, and a moral quality, on the other. For example, in his book No Future without Forgiveness, Desmond Tutu refers first to 'the African Weltanschauung' (Tutu 1999, p. 34), and then immediately goes on to say this: 'When we want to give high praise to someone we say, "Yu, u nobuntu"; "Hey, he or she has Ubuntu". This means they are generous, hospitable, friendly, caring and compassionate' (Tutu 1999, p. 34). However, it is much more common in the recent literature for a writer to refer to Ubuntu exclusively as a philosophy or ethic. For example, Venter (2004, p. 149) defines it as 'a philosophy that promotes the common good of society and includes humanness as an essential element of human growth'. Shutte (2001, p. 30) suggests that '[t]he goal of morality according to this 
ethical vision is fullness of humanity ... ' Finally, Hankela (2014, p. 2) defines Ubuntu as 'an African and South African communal, humane and hospitable philosophy, worldview or lifestyle'.

It is clearly a deeply challenging task to answer the question, what is Ubuntu? The provision of any kind of comprehensive answer is certainly beyond the scope of this essay. It is sufficient for our purposes to use a working definition. I approach Ubuntu as a humane and communitarian philosophy or ethic that views persons as interdependent entities whose deepest moral obligation is to become more fully human through expressing virtues such as openness to others, hospitality, generosity, and compassion.

We have approached participation from two angles-namely, through Wojtyla's philosophical treatment and Ubuntu. Given the different cultural contexts and patterns of thought, it is necessary to reflect on how the approaches relate to each other.

\section{Wojtyla's Philosophy of the Subject-in-Community and Ubuntu in Dialogue}

As we have seen, both systems of thought affirm positive interpersonal relations and a commitment to the common good. On the interpersonal level, relations need to be characterised by friendship, compassion, neighbourliness and justice. These positive relational behaviours, in turn, play a vital role in promoting the common good.

It is interesting in the context of this comparative exercise to note Metz and Gaie's (2010) work on what they see as the contrast between Aristotelian and other Western moral philosophies, on the one hand, and Ubuntu, on the other. They argue that there are two key differences between the Western and African approaches. The first is that 'Afro-communitarianism' is fundamentally relational in a way that Western systems are not. The second point of difference is that Ubuntu defines a positive relationship with others in strictly communal terms. What is interesting is that while this characterisation of differences may well apply to a number of Western moral philosophies, it is certainly not true in relation to Wojtyla's approach. As we have seen, his philosophy of participation is structured around positive interpersonal relations and a commitment to the common good.

We need to look elsewhere for a point of differentiation. I suggest that we find it in the way in which Ubuntu elevates harmony as the ultimate social value (Nussbaum 2003; Metz and Gaie 2010; Mkhize 2008). The overarching moral principle in an Afro-communitarian ethic is that the actions of a person are right to the extent that they promote harmony in the group. We do not find this notion in Wojtyla's philosophy.

While harmony is in principle a desirable state for a social body, the way in which some sub-Saharan communities seek to protect it results in quite negative outcomes. Louw (2001) offers important insights in this regard. He refers to this dark side of Ubuntu using Themba Sono's depiction of the 'tyrannical custom' of African culture and its 'totalitarian communalism'. According to Sono, the role of the group in African consciousness could be '...overwhelming, totalistic, even totalitarian' (Sono 1994, p. 7; cited in Louw 2001, p. 19).

Louw (2001) notes that this focus on the relation as defining of the human person can lead to a loss of certain valuable characteristics of personhood. He is thinking particularly of freedom and responsibility. Louw argues, however, that these values are not totally suppressed in Ubuntu. He cites the work of African philosophers who, while celebrating the distinctive African emphasis on collectivism and a collective sense of responsibility, also contend that this does not mean that individuality is negated. He comes to what I take to be a very important conclusion in relation to the true nature of Ubuntu: 'An oppressive communalism constitutes a derailment, an abuse of Ubuntu. By contrast, true Ubuntu incorporates dialogue, i.e., it incorporates both relation and distance. It preserves the other in his otherness, in his uniqueness, without letting him slip into the distance' (Louw 2001, p. 26).

Wojtyla's treatment of subject and community aligns with a correctly interpreted Ubuntu-namely, one in which subjectivity and the common good are held in tension. Subjectivity, for Wojtyla, is expressed through agency and self-possession. The moral individual both maintains agency and acts 
for the common good. Agency allows for self-determination; in this way, the individual establishes herself as a subjective structure of self-domination and self-possession.

We also find in Trinitarian theology a commitment to both distance and relation in interpersonal engagement. In Gunton's (1991) work on the imago Dei, for example, there is an attempt to identify a relational ontology in which the space between persons (distance and closeness) is properly defined. If there is too much space in the relational sphere there is a fall into individualism. Mutual participation in relationships implies nearness. Too little space, on the other hand, is also a problem. When the other sits on top of me, so to speak, I lose my freedom. She fails to make room for me and thereby shows a lack of respect for my otherness.

In developing his theological anthropology, Gunton picks up on the notion of the Greek theologians that God is a communion of persons. Each person is distinct and yet the Three indwell each other and so share in an essential unity. A close look at this understanding of the Trinity, suggests Gunton, will provide us with the right conceptualisation of relational space.

We have a conception of personal space: the space in which three persons are for and from each other in their otherness. They thus confer particularity upon and receive it from one another. That giving of particularity is very important: it is a matter of space to be. Father, Son and Spirit through the shape-the taxis—of their inseparable relatedness confer particularity and freedom on each other. That is their personal being. (Gunton 1991, p. 113)

According to Gunton (1991), the structure or taxis of human community is a relationality that involves both participation (nearness) and otherness (distance). The space between us has to be the right kind of space: we need 'the space to be'. 'To be a person is to be constituted in particularity and freedom - to be given space to be-by others in community. Otherness and relation continue to be the two central and polar concepts here. Only where both are given due stress is personhood fully enabled' (Gunton 1991, p. 117). In other words, relationality is 'polyphonic'. We need to play the notes of otherness and participation in harmony if we are to establish the right kind of relational space.

While true Ubuntu embraces both distance and closeness, there is a dark tendency associated with this philosophy. An over-valuation of group harmony often leads to closing down the interpersonal space. That is, the individual, a person with unique perspectives, insights, and preferences, is paid insufficient attention and respect. Subjectivity is suppressed and the individual person oppressed in the name of maintaining the unity and peace of the group. It is at this point that Wojtyla's philosophy and Trinitarian theology offer an important corrective. They both contain a polyphony of distance and relation. Unity and harmony in the community are prized, but at the same time the individual is given space to be. There is an in-built protection against a tendency to 'totalitarian communalism'.

Having given an indication of the light Trinitarian theology sheds on a participative ethic, it is time to develop this approach more fully. The focus in the next section is on 'I-Thou' and 'We' as key Trinitarian concepts.

\section{I-Thou and ' $W e^{\prime}$ in the Trinity}

There is now a very substantial body of theological work on the relational Trinity. Given that it is the relational Trinity that is the subject of the research, all theologians working in this area focus on social dynamics. There is quite a long list of theologians to choose from in the search for suitable conversation partners. I have chosen the following three theologians: Heribert Mühlen, Thomas McCall and Jürgen Moltmann. My choice is motivated by the fact that they construct their thinking around our two key categories-namely, 'I-Thou' and the 'We'. Mühlen's (1963) thought is especially significant for me because he explicitly develops the 'We' element; this dimension is only implicit in the other two Trinitarian theologies (Moltmann 1981; McCall 2014).

According to McCall (2014), the one God exists as three persons who live in a mutual-indwelling community of love. 'The divine persons are fully personal in the sense that they exist together as what may be called distinct speech-agents in what are sometimes referred to as "I-Thou relationships," 
and they exist only within their mutual relationships' (McCall 2014, p. 117). That is, a person is someone to whom personal pronouns apply. A person uses the word ' $\mathrm{I}$ ' and is addressed as a 'Thou'. McCall's (2014) argument is that even though human and divine personhood differ in important ways, there are genuine interpersonal relationships within the triune communion. In order to make his case, he turns to the Second Testament. There he finds numerous examples of descriptions of a robust interpersonal relationship between the Father and the Son. Jesus' birth and childhood fulfil the prophecy of Hosea 11:1: 'Out of Egypt I called my son' (Matt 2: 15). At Jesus' baptism, his Father gives expression to the love that unites them: 'This is my Son, whom I love' (Matt 3: 17). Jesus frequently uses intimate, loving language to describe his relationship with the Father, sometimes using the term Abba (Matt 7: 21; 10: 32-33: 12-50; 18: 10; 20: 23; 25: 34; 26: 29-42; Mark 14: 36). Jesus depicts his work and that of his Father as coordinated (John 5: 17-18; 6: 27-40), and the prayers of Jesus express a deeply intimate I-Thou relationship. Finally, the voice of the Father affirms his love for Jesus at the transfiguration: 'This is my Son, whom I love' (Mark 9: 7).

McCall (2014) argues that the depictions of the relationship between the Father and the Spirit in the Second Testament similarly reveal an I-Thou pattern. Jesus pledges the coming of the Holy Spirit (John 14: 16) as a fufillment of the promise of the Father (Luke 24: 48-49). Paul mirrors these ideas in his epistles, closely relating the Father and the Spirit, while maintaining their particularity (Rom 5: 5; 8: 14-16; I Cor 2: 4-5, 10-14; 3: 16; 6: 19; 14: 2; 2 Cor 5: 5).

According to McCall, we see the same interpersonal dynamic expressed in descriptions of the relation between the Son and the Spirit. The Holy Spirit is declared to be the agent of the virginal conception of Christ (Matt 1: 18-20; Luke 1: 35). The Spirit appears at the baptism of Jesus (Matt 3: 17; Mark 1: 9). It is the Spirit that leads Jesus into the wilderness and sustains him there (Matt 4: 1; Luke 4: 1-14). Jesus is empowered in his ministry by the Spirit (Luke 4: 18). Finally, Jesus promises that the Spirit will come as another Paraclete (John 14: 16), and that he will send the Spirit from the Father (John 15: 26). McCall (2014) concludes that '[s] uch considerations provide straightforward biblical support for a robustly relational view of divine personhood' (p. 118).

In his book, The Trinity and the Kingdom of God, Jürgen Moltmann similarly insists on the need to construe the triune life in I-Thou terms (Moltmann 1981). Moltmann begins by observing that both the major models of God in the history of theological thought stress the unity in the godhead and thereby fail to give due emphasis to its diversity. The first model is inspired by the Augustinian focus on the divine substance. The second paradigm is the Trinity of absolute subjectivity, as found in the philosophy of Hegel. Moltmann suggests that both Karl Barth and Karl Rahner, working as they do with theories of modes of being and manners of subsistence, align themselves with this tradition. He further contends that their view of the divine subject is grounded in the philosophy of individualism; they therefore fail to take account of the insight of the dialogical philosophers that the 'I' only exists in relation to the 'Thou'. Moltmann (1981) makes this important comment in this regard:

What Rahner calls 'our secular use of the word person' has nothing in common with modern thinking about the concept of person. What he describes is actually extreme individualism: everyone is a self-possessing, self-disposing centre of action which sets itself apart from other persons. But the philosophical personalism of Hölderlin, Feuerbach, Buber, Ebner, Rosenstock and others was designed precisely to overcome this possessive individualism: the 'I' can only be understood in the light of the 'Thou' — that is to say, it is a concept of relation. (p. 145)

Despite their shortcomings, the divine substance and Absolute Subject theories do at least clearly uphold divine unity. In rejecting these theories, Moltmann (1981) obviously needs to come up with an alternative way of securing oneness in the Godhead. He does this by employing a concept that we have alluded to a number of times-namely, perichoresis, or the mutual indwelling, of the three persons. Moltmann is convinced that in this way he has overcome the danger that looms large when one construes the triune God in terms of I-Thou relations-namely, a fall into tritheism. An individualistic 
concept of the person would result in tritheism precisely because it works with the notion of the ' $\mathrm{I}$ ' existing in itself and only subsequently entering into relation. But on Moltmann's view, the three persons are what they are in their particularity precisely because of their mutual relationships to one another and their co-inherence.

Mühlen's (1963) Trinitarian theology is significant in the context of our project because it incorporates both the 'I-Thou' and the 'We' domains that are central in Wojtyla's philosophy of subjectivity and community and in Ubuntu. He develops a theology of the triune God in which the Father is the 'I-statement', the Son is the 'Thou-statement', and the Holy Spirit is the 'We-statement' (Mühlen 1963, pp. 122-48). His first move is to discuss the 'Ich-Du-Verhältnis' (the I-Thou relationship) between the Father and the Son. He points out that Fatherhood suggests the existence of a Son. The Father as 'I' does not exist in 'I-aloneness' (Ich-Einsamkeit); he is the source of the eternally begotten Son. Though the Father does not possess any kind of priority in temporal terms (Father and Son are both eternal), there is a logical priority implicit in the term 'Father'. The Father is the unoriginated Source of the Son. The Father begets the Son in an act of infinite love.

The relationship of the begotten Son to the begetting Father is characterized by Mühlen (1963) as a Thou-relation. He uses an analogy with human relations to make his point. The 'Thou' in a conversation is that person from which the 'first' person - the ' $\mathrm{I}$ ' who has addressed the 'Thou' - expects a response. In the same way, the Son is the response-in-person to the loving call of the Father² (Mühlen 1963, p. 133). This mutuality in the loving relationship between the Father and the Son is an essential feature of the inner-Trinitarian life. According to Mühlen (1963), the love of the Father for the Son is directed to the Son as 'the Son of the Father', and returns in the Beloved Son to the Father himself. And this situation is fully reversible: the love of the Son for the Father is directed to the Father as his Father, and returns in his beloved Father to the Son.

Mühlen (1963) goes on to point out that this mutuality in the divine love extends beyond the relationship of the Father and the Son to include the Holy Spirit. This reflexivity in the divine self-love is a central focus in his discussion. The circle of life in the godhead is closed within itself. In an act of perfect love, the Father begets the Son and the Father and the Son together spirate or breathe out the Spirit. Following the lead of Thomas Aquinas, Mühlen states that with the procession of the Holy Spirit the divine circle of life is closed; no third procession follows. It is in the Holy Spirit that the divine self-love returns to itself. This is the essential meaning of the 'We' in the Trinity. That is, the Holy Spirit is the 'We' because it is through the agency of the Holy Spirit that the divine self-love returns to the Father and to the Son in the same moment ${ }^{3}$ (Mühlen 1963, p. 142).

Another way of talking about the 'We' in Trinitarian terms is perichoresis. In discussing this ancient theological notion, support is given to my contention that the participatory humanness that is the foundation of both Wojtyla's philosophy and Ubuntu aligns with a view of the human person as made in the image of the Trinity. Gabriel Setiloane makes this telling comment in relation to Ubuntu: 'the essence of being is participation in which humans are always interlocked with one another ... the human being is not only "vital force", but more "vital force" in participation' (Setiloane 1986, p. 14; cited in Mcunu 2004, p. 27). The concept of perichoresis expresses a particular type of participation. The Three mutually indwell each other in and through love. South African theologians are similarly drawn to the Ubuntu-perichoresis link (Manganyi 2012; Williams 2013). Given that the human person is created imago Trinitatis (in the image of the Triune God), it is legitimate to claim that the Ubuntu and Christian theological views of the human correlate. According to Christian theology, humans are made for participation; it is a virtue that we need to live out in every domain of our existence.

Cunningham (1998), writing out of a North American context, refers to participation as one of the essential Trinitarian 'virtues' (he identifies three of these). In using this descriptor, he indicates

\footnotetext{
'die Ant-Wort in Person auf den Liebesruf des Vaters'.

'In diesem Sinne kann man sagen, da $\beta$ im Hl. Geiste die göttliche Selbstliebe zum Vater and zum Sohne zurückkehrt, und zwar zum Vater und zum Sohne zugleich.'
} 
that the divine life is first and foremost an event of mutual indwelling. Interestingly, he also makes a connection with perichoresis. It 'describes the Three as indwelling and interpenetrating one another so completely that we can never intelligibly speak of one without involving, at least implicitly, the other two as well. The Three exist in a dynamic interrelationship with one another, giving to and receiving from one another what they most properly are' (Cunningham 1998, p. 115).

Further, participation is a virtue that we humans are also called to enact. If the doctrine of the Trinity has anything to say about authentic existence, it is that communion rather than individualism is the goal of human life. Participation, according to Christian theology then, is a Trinitarian ethic that marks human existence.

\section{Conclusions}

The virtue of participation is being-with and acting-for others with the aim of advancing the common good. Karol Wojtyla's philosophy of subjectivity and community and the Ubuntu ethic approach participation in a particular way-namely, through positing both an 'I-Thou' and a 'We' dimension. Despite their substantial commonalities, what distinguishes them is the fact that Ubuntu establishes harmony as the superordinate social value in a way that Wojtyla's theory does not. The shadow side of Ubuntu (in practice, rather than in principle) is domination and oppression of the individual in seeking to maintain harmony at all costs. Wojtyla's dual emphasis on subjectivity and community, which is also found in Trinitarian theology, corrects for the shadow side, and points towards the true meaning of Ubuntu.

These two philosophies are not overtly theological. Though Christians will instinctively resonate with these ethical models, it is necessary to make the theological alignment explicit. In engaging with Trinitarian theologies that mirror Wojtyla's embrace of both the 'I-Thou' and the 'We' domains, it becomes clear that participation is a Trinitarian ethic. When individual Christians, together with their communities, commit to a participatory ethic, they reflect-albeit very dimly-the perichoretic life of the triune God.

Conflicts of Interest: The author declares no conflict of interest.

\section{References}

Bernstein, Ann. 2002. Globalization, Culture, and Development: Can South Africa be More Than an Offshoot of the West? In Many Globalizations: Cultural Diversity in the Contemporary World. Edited by Peter Berger and Samuel Huntington. New York: Oxford University Press, pp. 185-249.

Buber, Martin. 1961. Between Man and Man. Translated by Ronald McGregor Smith. London: Collins.

Buber, Martin. 1970. I and Thou. Translated by Walter Kaufmann. Edinburgh: T\&T Clark.

Cunningham, David. 1998. These Three are One: The Practice of Trinitarian Theology. Malden: Blackwell.

Ebner, Ferdinand. 1967. Word and Personality. Philosophy Today 11: 233-37.

Ebner, Ferdinand. 2001. Mühlauer Tagebuch 23.7-28.8.1920. Commentary by R. Hörmann and M. Seekircher. Vienna: Böhlau Verlag.

Gade, Christian. 2011. The Historical Development of the Written Discourses on Ubuntu. South African Journal of Philosophy 30: 303-29.

Gade, Christian. 2012. What is Ubuntu? Different Interpretations among South Africans of African Descent. South African Journal of Philosophy 31: 484-503.

Gunton, Colin. 1991. The Promise of Trinitarian Theology. Edinburgh: T\&T Clark.

Hankela, Elina. 2014. Ubuntu, Migration and Ministry. Leiden: Brill.

Louw, Dirk J. 2001. Ubuntu and the Challenges of Multiculturalism in Post-apartheid South Africa. Quest XV: 15-36.

Manganyi, Jele. 2012. Church and Society: The Value of Perichoresis in Understanding Ubuntu with Special Reference to John Zizioulas. Ph.D. dissertation, University of Pretoria, Pretoria, South Africa.

Manganyi, Jele S., and Johan Buitendag. 2013. A Critical Analysis on African Traditional Religion and the Trinity. HTS Teologiese Studies/Theological Studies 69: 1-13. [CrossRef] 
Marcel, Gabriel. 1964a. Phenomenological Notes on Being in a Situation. In Gabriel Marcel, Creative Fidelity. Translated by Robert Rosthal. New York: The Noonday Press, pp. 82-103.

Marcel, Gabriel. 1964b. Belonging and Disposability. In Gabriel Marcel, Creative Fidelity. Translated by Robert Rosthal. New York: The Noonday Press, pp. 38-57.

McCall, Thomas. 2014. Relational Trinity: Creedal Perspective. In Two Views on the Doctrine of the Trinity. Edited by J. S. Sexton. Grand Rapids: Zondervan, pp. 113-37.

Mcunu, Tobias. 2004. The Dignity of the Human Person: A Contribution of the Theology of Ubuntu to Theological Anthropology. Masters' thesis, University of South Africa, Pretoria, South Africa.

Metz, Thaddeus, and Joseph B. R. Gaie. 2010. The African Ethic of Ubuntu/Botho: Implications for Research on Morality. Journal of Moral Education 39: 273-90. [CrossRef]

Mkhize, Nhlanhla. 2008. Ubuntu and Harmony: An African Approach to Morality and Ethics. In Persons in Community: African Ethics in a Global Culture. Edited by Ronald Nicholson. Pietermaritzburg: University of KwaZulu-Natal Press, pp. 35-44.

Moltmann, Jürgen. 1981. The Trinity and the Kingdom of God. London: SCM Press.

Mühlen, Heribert. 1963. Der Heilige Geist Als Person. Münster: Aschendorff.

Nussbaum, Barabara. 2003. Ubuntu: Reflections of a South African on our Common Humanity. Reflections 4: 21-26. [CrossRef]

Ramose, Mogobe. 1999. African Philosophy through Ubuntu. Harare: Mond Books.

Setiloane, Gabriel. 1986. African Theology: An Introduction. Johannesburg: Skotaville.

Shutte, Augustine. 2001. An Ethic for a New South Africa. Pietermaritzburg: Cluster Publications.

Sono, Themba. 1994. Dilemmas of African Intellectuals in South Africa. Pretoria: UNISA.

Tutu, Desmond. 1999. No Future without Forgiveness. London: Rider.

Van Binsbergen, Wim. 2001. Ubuntu and the Globalisation of Southern African Thought and Society. Quest: An African Journal of Philosophy 15: 53-89.

Venter, Elza. 2004. The Notion of Ubuntu and Communalism in African Educational Discourse. Studies in Philosophy and Education 23: 149-160. [CrossRef]

Williams, David. 2013. Perichōrēsis and the South African Ideal. Koers: Bulletin for Christian Scholarship 78: 1-7. [CrossRef]

Wojtyla, Karol. 1979a. The Acting Person. Translated by A. Potocki. Dordrecht: D. Reidel Publishing Co. Wojtyla, Karol. 1979b. The Person: Subject and Community. The Review of Metaphysics 33: 273-308. 